\title{
Understanding the Conservation Activities in Sumberpitu Water Springs Using Causal Loop Diagrams
}

\author{
$1^{\text {st }}$ Ferryati Masitoh \\ Department of Geography \\ State University of Malang \\ Malang, Indonesia \\ ferryati.masitoh.fis@um.ac.id
}

\author{
$2^{\text {nd }}$ Alfi Nur Rusydi \\ Department of Information System \\ University of Brawijaya \\ Malang, Indonesia \\ alfi.nurrusydi@ub.ac.id
}

\begin{abstract}
Sumberpitu water springs was the one of primary resources, not only for people living in around of Bromo Mountain, but also for people living in Malang City. The water spring was very important for them to sustain their life activities. The importance of that urged people to be aware how important conservation activities was. Understanding conservation activities was done using System Dynamics approach which was part of system thinking helping to be understand real life condition. Causal Loop Diagram (CLD) is a system dynamics form having feedback among the variables. Water-Human-Land System (WHLS) Sumberpitu water spring Conservation was used as CLD Model. The CLD Model used Groundwater Storage including Sumberpitu water spring, Built- Up/Opened Area and Agricultural Areas in the Upper stream of water springs, and Rural and Urban Population as primary variable. The variables have both influence and feedback to each other. Conservation activities were done by local people including water prices variable as environment services charge, conservation education variable, and Adat Karo traditional ceremony as a local wisdom. For sustaining Sumberpitu water spring use, the conservation activities were expected to control, not only water use, but also land use change in the upper stream of water springs.
\end{abstract}

Keywords: conservation activities, causal loop diagrams

\section{INTRODUCTION}

Water springs is groundwater coming out to the ground surface. Water springs can be easily found in the break of slope of mountainous areas. The Sumberpitu water spring was a spring group located on the cliffs of the Gentong River. There were 7 water springs and seepages. The water springs were used as water consumption for both the rural and the urban people population. Increasing fresh water needs occurred because of increasing total population growth including its activities [1]. Both water security and water environmental security were parts of water security system [2]. Water springs were often to be the main of water security system in the mountainous area.

Water spring could be classified by its physical rock properties. Thick layer and loose sediment including gravel delivered spring resulted from pore aquifer. Water spring caused by fault and fracture was formed from fracture, cleavage, and fault of compact rock, for instance igneous rock. Spring could also be shaped from carbonate rock delivering tubular spring and solutional limestone cave [3].

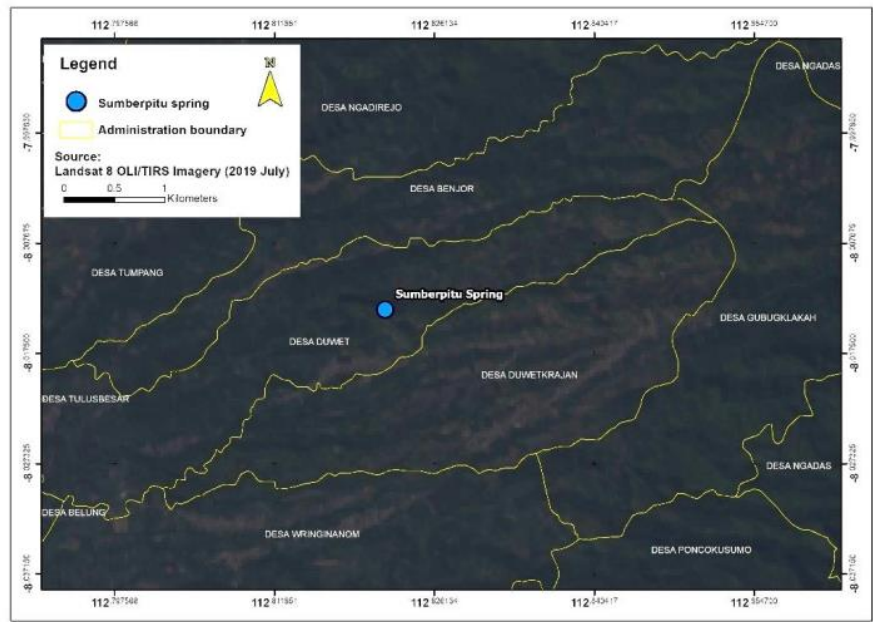

Fig 1. Location of Sumberpitu water spring

Sumberpitu water spring was located in Tumpang Subdistrict, Malang Regency, East Java Province. It was part of Bromo Tengger Semeru National Park (TNBTS). TNBTS had some zones. Each zone had function based on its geographical condition. The zones consisted of Core Zone (17.028, $67 \mathrm{Ha})$, Jungle Zone (26.806, $31 \mathrm{Ha})$, Utilization Zone (1.193, $43 \mathrm{Ha})$, 
Rehabilitation Zone (2.139,19 Ha), Traditional Zone (3.041,86 $\mathrm{Ha})$, Specific Zone $(61,56 \mathrm{Ha})$, and Religious Zone $(5,18 \mathrm{Ha})$ [4]. The Utilization Zone was zone which Sumberpitu water spring located in. In this zone, all resource utilizations, including water spring use might be permitted by TNBTS manager [5]. As part of National Park, Sumberpitu spring required conservation activities of water spring use. The research aims to understand conservation activities by local people around the water spring location. To do so, the Causal Loop Diagram approach was used.

Causal Loop Diagram (CLD) is part of System Dynamic. System Dynamic is a paradigm model of feedback analysis developed by JW. Forester (1958). As part of System Thinking, the system has ability to observe real world as a complex perspective and to understand about interactions of things to each other [6]. System dynamic is represented as Causal Loop Diagram functioning as initial analysis to understand the core mechanism of cause-effect system. [7]. CLD is the core of the System Dynamic modelling. [8]. CLD is represented as feedback interactions by arrow symbols indicating cause-effect (causality) among influence variables to the system [8]. CLD can also be called as Influence Diagram [9].

\section{METHODS}

This research used quasi qualitative approach to analyze both condition and conservation activities of water spring. It also used related theories and numeric data to support the arguments of that analysis. Data used consisted of primary data and secondary data. Primary data included field surveying data and interviewing of informant data. The inclusive criteria of informant interviewed was people involved in conservation activities of Sumberpitu water spring. Secondary data used were Landsat 8 OLI/TIRS Imagery, Rupa Bumi maps scaled of 1:25.000 sourced from Geospatial Information Board, and Digital Elevation Model (DEM) of SRTM 30 meters resolution imagery sourced from USGS.

The research used descriptive analytic approach to explain the facts of conservation activities using System Dynamic model. Implementation of System Dynamic did not consider the processes occurred in the conservation system, so that the model was represented as a black box system. System Dynamic of conservation activities was modelled as Causal Loop Diagram (CLD).

CLD variables formed 2 behaviors, which were reinforcing behavior and balancing behavior in the system (see Fig 2). Reinforcing behavior was signed of "+" (positive), whereas balancing behavior was signed of "-" (negative). CLD modelling used phases which were labelling phase an CLD structuring phase. In labelling phase, stocks variables and auxiliary variables were determined followed by the link prediction and influence information variables. In structuring phase, the manual process was done to determine variables relationship based on facts of the system [7].

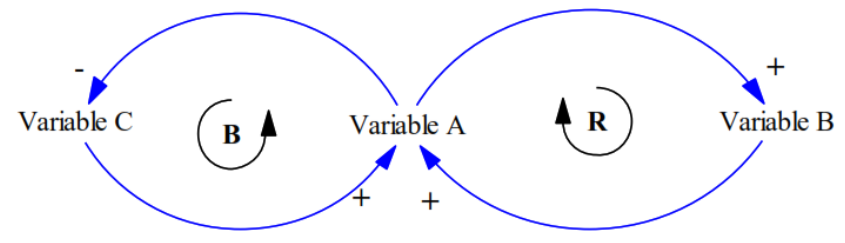

Figure 2. Causal Loop Diagram/CLD

CLD had interdisciplinary characteristic and it focused on dynamic behavior to nonlinear feedback system. The advantage CLD used to understand the system were representing mental model, providing dynamic complexity, and informing causeeffect relationship by feedback [6], [10]. CLD had been used well to understand water services sustainability, financial, business and management, forestry, and residence problems [7], [8], [10], [12].

\section{RESULTS AND DISCUSSION}

There were 2 CLD subsystems of conservation activities in Sumberpitu water spring. They were Water- Human Subsystem and Water-Land Subsystem. Water variable was divided into water quantity variable and water quality variable. Water quantity variable consisted of Groundwater Storage, springs discharge, domestic water consumption (for urban and rural), and nondomestic water consumption (for agriculture) in the downstream area of springs, and water infiltration. Water quality variable consisted of polluted water located in the upper stream area and the downstream area of spring. Human variables consisted of rural people population of around the water springs, and the urban people population of Malang City. Land variable consisted of built up area, land conversion rate, agricultural area, built up area ratio, and available land. The land variable was in the upper stream of springs.

\section{A. Water-Human Subsystem}

Water needs always increased followed by both people population growth and economic development. Water needs was always acquired by groundwater use [13]. Water needs of mountainous area depended on water spring existence. Water spring was occurred by part of groundwater appearing to the ground surface. Based on hydrogeology perspective, Sumberpitu water spring belonged to Hydrogeology System of Bromo Mountain which had moderate level of water productivity in wide distribution area. The water appeared because of high igneous rock porosity [14]. The groundwater was sourced from water precipitation (rain) infiltrated into the ground, then it flowed down from upper stream area to downstream area which had lower topographic elevation level [15]. 


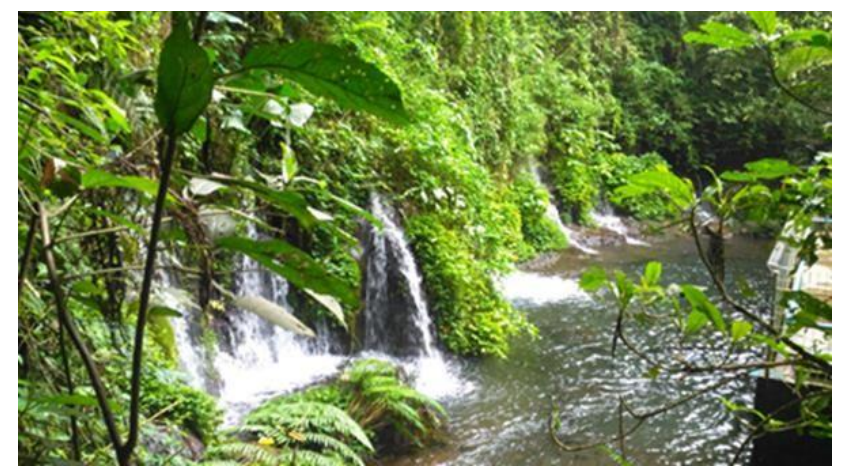

Fig 3. Sumberpitu water springs

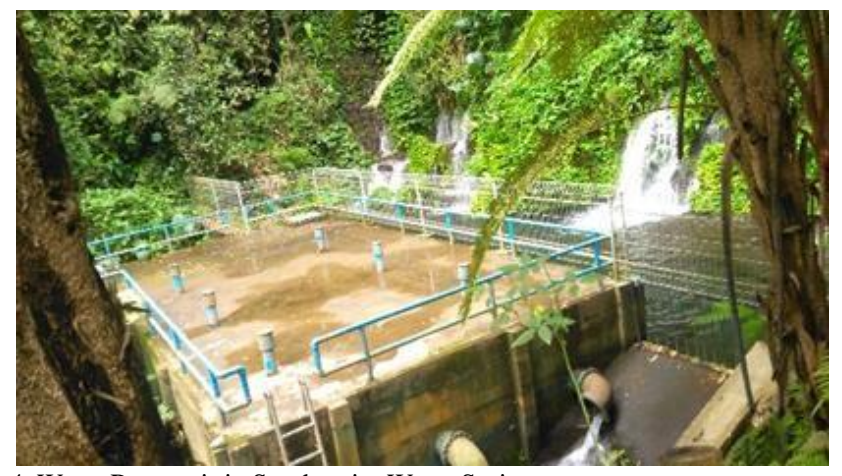

Fig 4. Water Reservoir in Sumberpitu Water Springs

Water coming out from the spring shaped river system. Sumberpitu water spring could be found on the cliff of Gentong river. People used the water spring as domestic and agricultural needs. They must pay of $300,00 \mathrm{IDR} / \mathrm{m}^{3}$ for water spring services charge to fulfil domestic needs. The payment of 600,00 $\mathrm{IDR} / \mathrm{m}^{3}$ was charged to people who used the water for agricultural needs. Those payments were used as water spring conservation activities rate. Some people used the water for home industry's needs. They were charged to pay more expensive rate than both previous needs (based on observation and interview)

Flowing water was stored into a water reservoir which was the product of Regional Governmental Company of Water Supply (PDAM) program. Overall, water discharge coming out from Sumberpitu spring was up to 400 liter/second, but the water discharged stored into the reservoir was only 200 liter/second. The stored water will be distributed through pipelines networks to urban people of Malang City [16].

The figure 5 explained that CLD Water-Human Relationship in Sumberpitu water spring was represented as subsystem. The Water-Human Relationship subsystem had variables including groundwater storage, springs debit, water consumption for domestic/agricultural/urban people needs, water prices for domestic/agricultural/urban people activities, polluted water in the upper/downstream of springs, and water infiltration. The relationship had 2 reinforcing loops ( $\mathrm{R} 1$ and $\mathrm{R} 2$ ). Loop of $\mathrm{R} 1$ had variables including groundwater storage - water springs discharge - water consumption for domestic needs. Increasing of groundwater storage would be followed by the increasing of water spring discharge. Water consumption for domestic needs was influenced by total of people population and the water price. Total of people using water spring up to in year of 2019 was getting to 1.251 people or 700 families. Water discharge that might be permitted to be used by people was 0,96 litre/second [5]. The water was distributed to all local people using pipelines of 6 kilometres. Pipeline network infrastructures was built up using local government fund as its funding support. Permission use allowed for local people was limited only for noncommercial water needs. The water not used for any needs was flowed through canals located in along local roadside. That water would flow into drainage and river system. Some people lived not only in around water spring itself, but others also lived in downstream area. Increasing water consumption for any people activities could reduce total of groundwater storage of water spring.

Total of groundwater storage was recharged from infiltration process. Infiltration process comes from precipitation and some were infiltrated into the ground [15]. The infiltrated water resulted from that precipitation process did not be polluted. The water pollution was possible to be occurred by some water used for people activities and that water could contaminate the river and the groundwater. Occasionally, water used for domestic needs contained toxic pollutant and it was able to contaminate the water bodies [17]. Increasing people population growth reduced stored water and added to the total of polluted water [18].

Water spring was also used to support agricultural irrigation activities by local people. Water use for agricultural was influenced by types and total hectare of agricultural area. That water would be polluted water containing chemical properties resulted from chemical fertilizer and pesticide [17]. Sumberpitu water spring located on the river cliff was recharged by the water located in upper stream area. Some of the upper stream areas were still covered by forest and the remaining areas were covered by agricultural land. People and TNBTS stakeholder forbid any agricultural activities using chemical fertilizer and pesticide, since it could be potential to contaminate the water spring. There was some polluted water because of people activities in downstream area located around the village and Malang city. But, those water did not contaminate the Sumberpitu water spring, since the water spring was coming from hydrogeology system of upper area in Bromo Mountain [14]. 


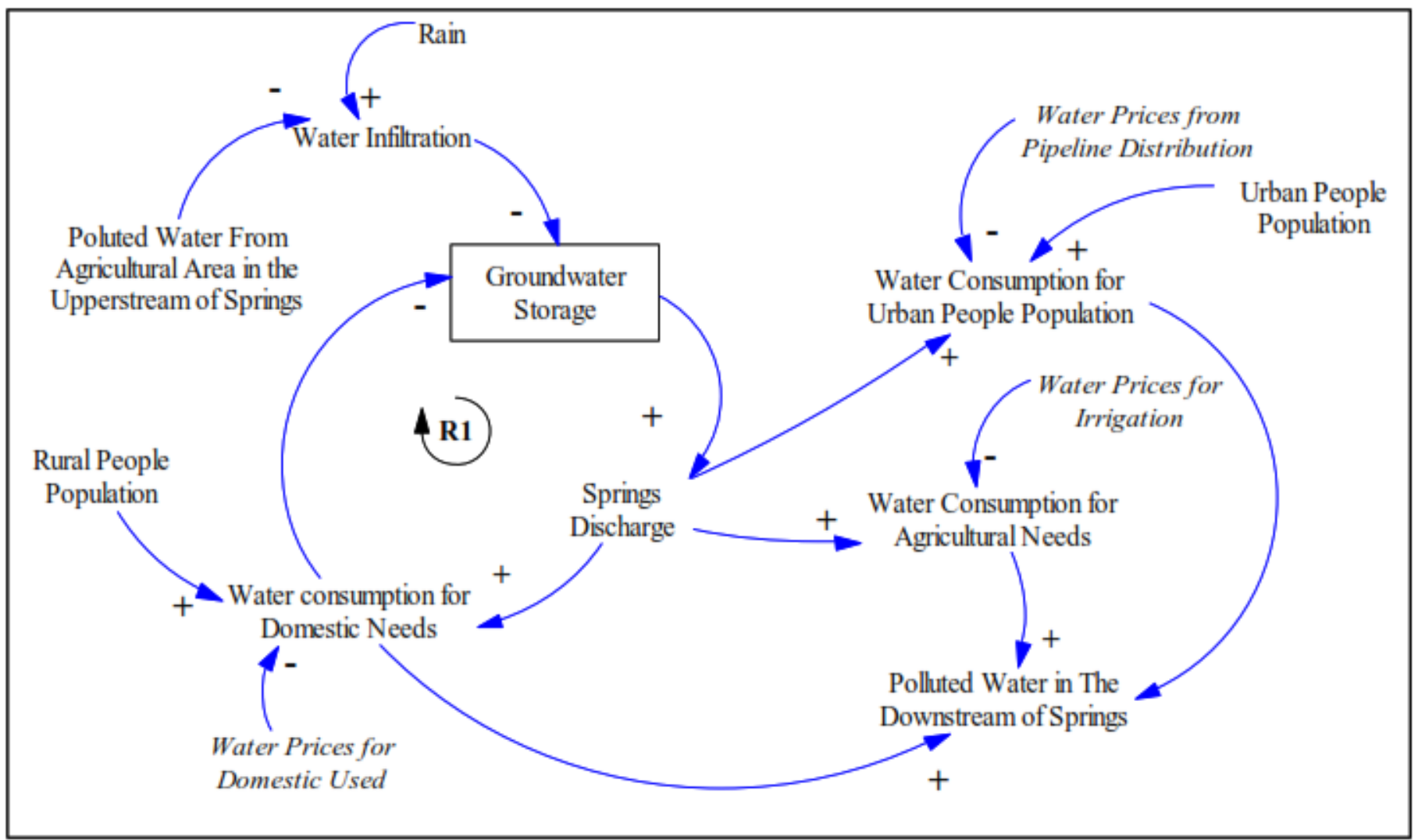

Figure 5. CLD of Water-Human Subsystem

Urban people population used water spring for their needs using distributed water pipelines. Water consumption of urban people was influenced by total of people (within their activities) and water price. Standard water price in urban by using distributed water pipelines was about $5.400,00 \mathrm{IDR} / \mathrm{m}^{3}$. The price has been increased ranging from in years of 2013-2014 that was about $4.096,00 \mathrm{IDR} / \mathrm{m}^{3}$ and in years of 2015- 2017, it increased up to $\mathrm{Rp} 5.243,00 \mathrm{IDR} / \mathrm{m}^{3}$. That price was not be used specifically for water spring conservation, but only be used for producing and distributing. The government targeted about 50\% of water needs in Malang City supplied by Sumberpitu water spring [19]. Other water resources were not belonging in CLD Sumberpitu Conservation system included Wendit water spring and engineered groundwater well. The high rate of water price would be able to control the total of water consumption by people.

\section{B. Water-Land Subsystem}

Water-land subsystem of Sumberpitu water spring conservation activities had variables including Groundwater Storage, Environmental Carrying Capacity, Land Conversion Rate, Agricultural Area, Built Up/ Opened Area, Run Off, Polluted Water in the Upper stream of Spring, Water Infiltration. Groundwater Storage variable was total amount of groundwater stored in Hydrogeology system influenced by aquifer of Bromo Mountain. Groundwater Storage was coming out to ground surface as water spring. In Water-Land Subsystem, there were 2 causal loops which are B1 and B2. Both loops are negative (balancing) loops.

Loop of B1 formed causal loop of Groundwater Storage Environmental Carrying Capacity - Land Conversion Rate Agricultural Area - Run Off - Polluted Water in The Upper Stream - Water Infiltration- Groundwater Storage. Loop of B2 formed causal loop of Groundwater Storage - Environmental Carrying Capacity - Land Conversion Rate - Built Up/ Opened Area - Run Off - Polluted Water in The Upper Stream - Water Infiltration - Groundwater Storage. Groundwater as a water resource and socio-economic development were close correlated with indefinite future of a region [20]. Environmental Carrying Capacity involved land and water in a hydrology relationship. Land condition and people population depended intensely on available water resource. Limited water resource would be a more important constrain than land. Available water resource could be changed since of socio-economic changes of water use. Land use exploited extremely would influence environmental carrying capacity [18]. 


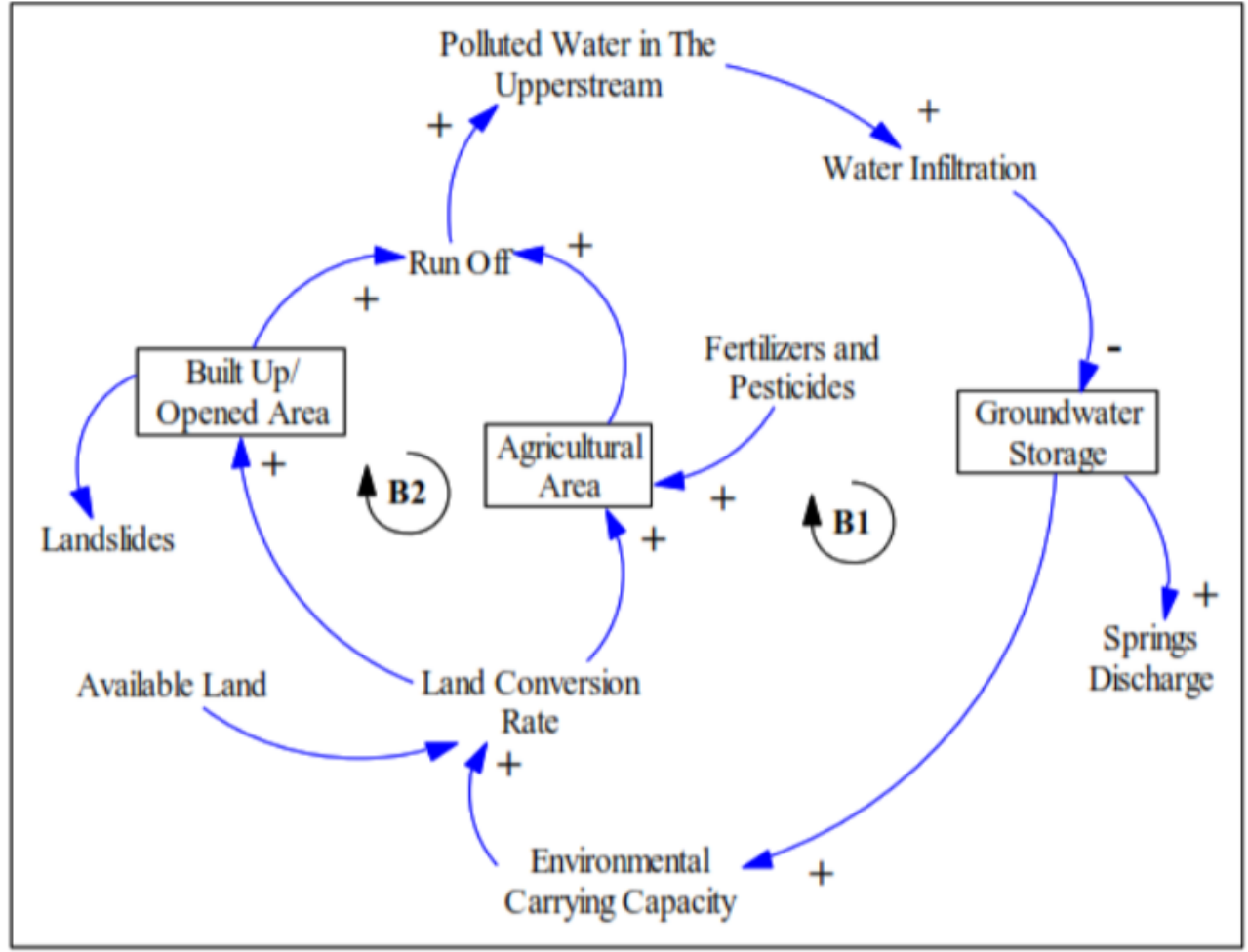

Figure 6. Water-Land Subsystem

Land Conservation Rate was influenced by both Environmental Carrying Capacity and Available Land. Available land would restrict Land Conservation Rate. High Land Conservation Rate for changing of forest to be other land use types depended on rural-urban migration that required new land as built-up land or agricultural land [21]. Water resulted from agricultural activities would be runoff. Chemical agricultural cultivation used fertilizer and pesticide would acquire polluted runoff [17].

\section{Water-Human-Land System as a Conceptual Model of Springs Conservation}

Figure 7 showed combination of Water-Human Subsystem and Water-Land Subsystem of Sumberpitu water spring. In Water-Human-Land (WHLS), there were 3 loops consisting of 1 reinforcing loop (R1) and 2 balancing loops (B2 and B3). Loop of R1 was Water-Human Subsystem, whereas Loop of B2 and loop of B3 were Water-Land Subsystem. Integration of water, human, and land formed a dynamic conservation system [22]. WHLS of water spring conservation would deliver the real word facts about the intercorrelation of related things and their feedback in the system.

In WHLS, there were 3 variables showing water users of Sumberpitu spring. They were rural/local people, farmer, and urban people. Water coming out from the spring was one of environmental part to support daily people activities. People had to pay the environmental services as financial charge of environment use by them [23]. In WHLS, payment of water use was represented as water price variable. Water used would be waste. The waste contained polluted water by other substance that could taint the other water bodies. [17]. In environmental conservation, people contaminating (polluters) the environment had to pay its negative environment impacts (Polluters Pays Principles) [24]-[26]. All people involving into WHLS variable did not pay the water price as that Polluters Pays Principles, but the total their payment was just as environmental services charge of water use. Determining the water price of that services was done by people agreement and requirement. For local people, determining the water price was done by routine people discussion held in public hall. They believed that the water price could control their water use, so that sustainable of Sumberpitu water spring were wished to be reached. For urban people, environmental services charge was coordinated by a pipelines network company. That company would pay the water price to Local Government of Malang District who has rights to own and to control the Sumberpitu water spring. 


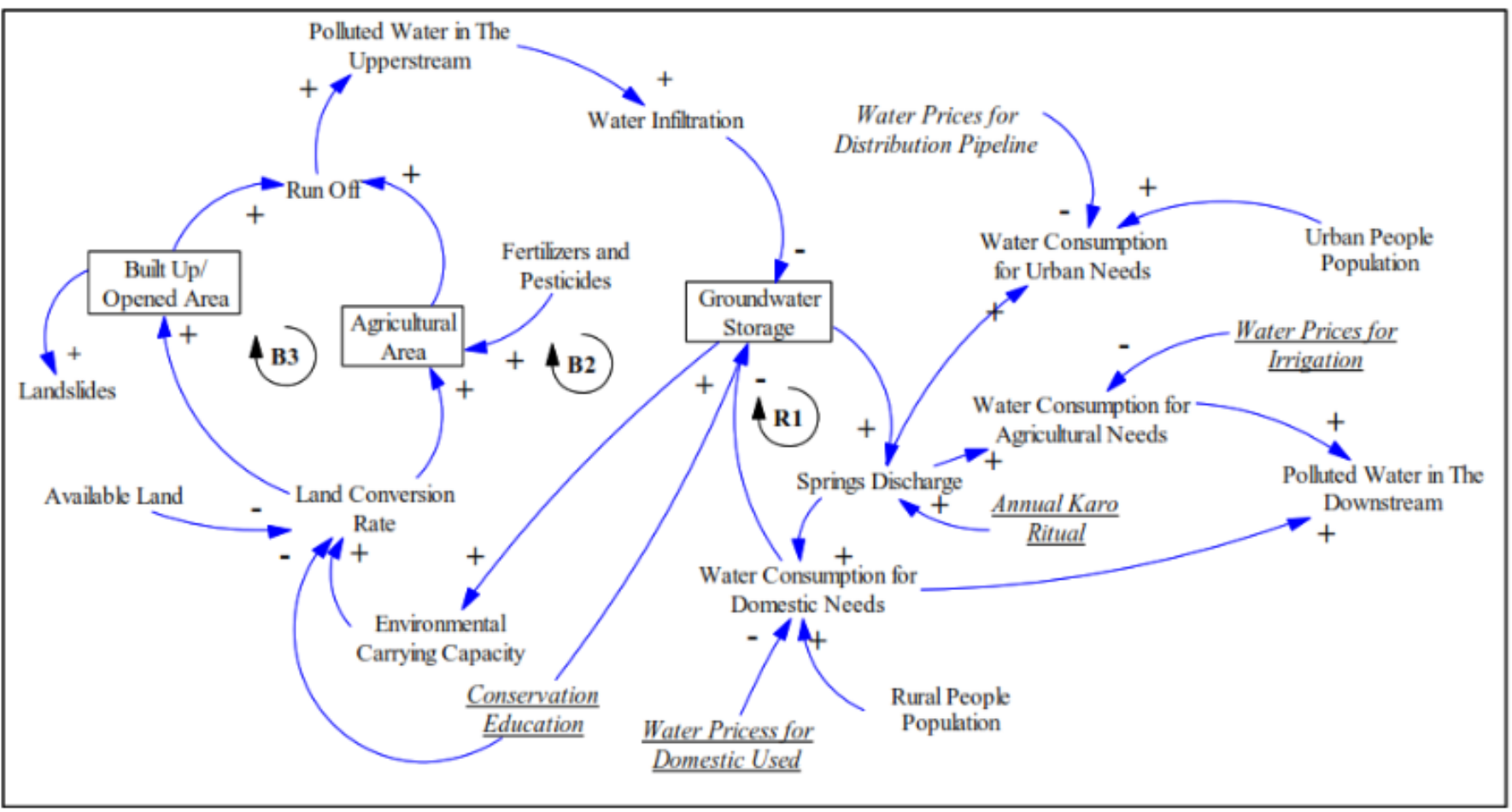

Figure 7. Causal Loop Diagram Water-Human-Land System (WHLS) Sumberpitu water spring conservation.

Deforestation is a forest conversion to be other land use types. Deforestation correlated to people needs of land. Impact of deforestation is environmental degradation [22]. That conversion was to be threat that potentially occurred in Sumberpitu water spring. Economic interest was main cause of land conservation [27]. Land conversion did not only occur in upper stream area, but also occurred in downstream area (surrounding rural, agricultural land, and urban). The research focused only on land conversion occurred in upper stream area (see Fig.8). It was done since that area would influence significantly the water availability and water quality of Sumberpitu water spring.

Based on Landuse map, the lands located in upper stream area were dominated by vegetation cover as plantation and forest. The plantation owned by local people consisted of fruits plantation (apple and orange), agricultural land (banana, cabbage, and bean), and other kinds of plantation. Location distance between local people residence to water spring located in was about 2 kilometers that was dominated land cover ranging from moderate/low to high density vegetation area. That vegetation areas were forest, mixed plantation, and agricultural plantation. Like upper area condition, in this area, people were suggested not to change the forest to be other land use types. The suggestion was done through environmental care socialization held at routine people discussion. In WHLS, the suggestion was represented as Conservation Education variable as integrated part of water spring conservation activities by local people. Education was one of the ways that could be used to increase people understanding of their environment [28]. Other way of local wisdom for increasing environment understanding by local people were formal law and traditional law. Local wisdom of environment management in each region had its own uniqueness and generally adapted it based on its own ecological condition [29], [30]. The local wisdom form by local people of Sumberpitu was Adat Karo traditional ritual. Ceremony of Karo ritual was annual activity by local people living in surrounding Sumberpitu waterspring. It was held by local people as their thanks to God and respectful honour to water spring that had given a lot of benefit for them.

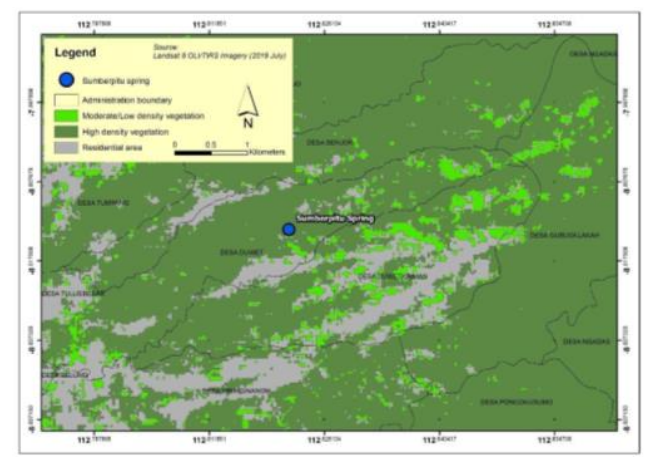

Figure 8. Landcover around in the Sumberpitu water spring 


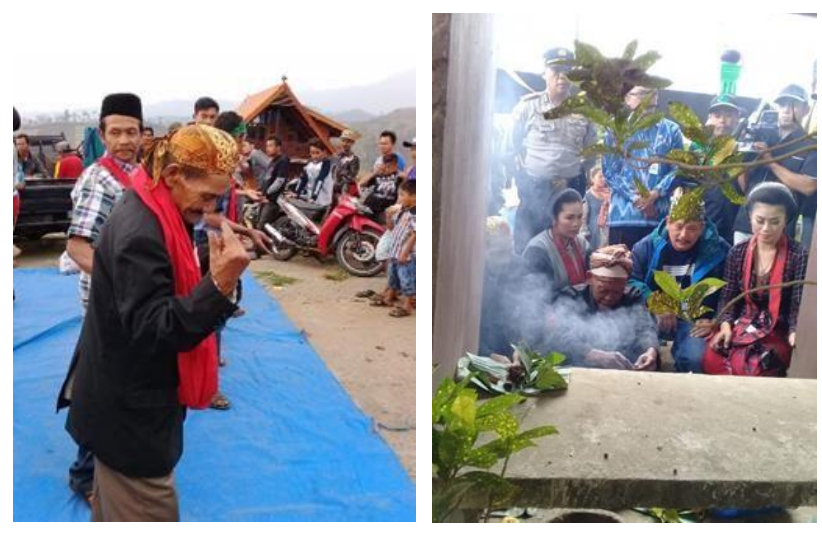

Figure 9. Adat Karo Traditional Ceremony

Figure 9 showed Adat Karo traditional ceremony. The ceremony was held as local community praying expression because of God's blessing upon benefits of Sumberpitu existence and its sustainability. The ceremony was held at the highest rate of water spring discharge. It occurred in early of October. The ceremony activities consisted of opening, core, praying, and closing. The opening consisted of thanks statement of local people to God and all creatures including not visible creatures that keep water spring safe. The core of ceremony consisted of tribute dancing, delivering yellow rice served in cone shape (Javanese: tumpeng) to around water spring location, and ritual offering with incense. The praying expression used combination of Javanese language and Islamic invocation (sholawat) followed by closing speech. The ceremony involved all local people of Sumberpitu water spring and it was coordinated by elders including village leader/tradition leader. Cultural approach was proven to be effective if it applied in areas which had high moral values of cultural tradition, for instance in the Sumberpitu water spring

\section{CONCLUSION}

System dynamic is one of system thinking helping to understand real word as compressive perspective. Causal Loop Diagram (CLD) is one of system dynamic representing real word model within intercorrelation and feedback. Implementation of CLD to understand conservation activities in the Sumberpitu water spring was represented as Water-HumanLand System (WHLS). The WHLS integrated both water and land conservation into people activities. Water consumption for domestic needs was influenced by total of people population and their activities. Intensity of people activities influenced the water quality that might add the total of polluted water. Water price can control the total of water consumption, so that sustainability of Sumberpitu water spring system can be achieved. The WHLS showed universally how conservation activities occurred in the Sumberpitu water spring.

\section{REFERENCES}

[1] BPS, STATISTIK AIR BERSIH JAWA TIMUR 2015 / 2016. 2016.

[2] Z. Chen and S. Wei, "Application of System Dynamics to Water Security Research,” Water Resources Management, vol. 28 No. 2, no. January, pp. 287-300, 2014

[3] H. Hendrayana, HIDROGEOLOGI MATA AIR, no. September. Gadjah Mada University, 2013.

[4] TNBTS, "Pembagian Zonasi TNBTS." [Online]. Available: http://bromotenggersemeru.org/page- static/zonasi. [Accessed: 11-Jul2019].

[5] BBTNBTS, Pemberian Izin Pemanfaatan Air Kepada Kelompok Pemanfaat Air Desa Duwet Krajan, Tumpang, Malang, di Kawasan Taman Nasional Bromo Tengger Semeru. Malang: Balai Besar Taman Nasional Bromo Tengger Semeru, 2016.

[6] J. D. Sterman, "SYSTEM DYNAMICS: SYSTEMS THINKING AND MODELING FOR A COMPLEX WORLD," 2002.

[7] T. Binder, A. Vox, S. Belyazid, H. Haraldsson, and M. Svensson, "Developing system dynamics models from causal loop diagrams," no February 2014, 2004.

[8] J. H. Kim, S. Lee, and J. Kim, "Causes Analysis of Unsold New Housing Stock by Causal Loop Diagram CAUSES ANALYSIS OF UNSOLD NEW HOUSING STOCK,” 2011, no. June 2017.

[9] A. Ganjidoost, C. T. Haas, M. A. Knight, and A. J. A. Unger, "A System Dynamics Model for Integrated Water Infrastructure Asset Management." [Online]. Available https://pdfs.semanticscholar.org/0184/b0d94c4c24352557c758ad8d7aaa 0c7c29c5.pdf. [Accessed:11-Jul-2019].

[10] B. Kiani, M. R. Gholamian, and A. Hamzehei, "USING CAUSAL LOOP DIAGRAM TO ACHIEVE A BETTER UNDERSTANDING OF EBUSINESS MODELS," International Journal of Electronic Business Management, vol. 7, no. 3, pp. 159-167, 2009.

[11] K. Neely and J. P. Walters, "Using Causal Loop Diagramming to Explore the Drivers of the Sustained Functionality of Rural Water Services in Timor-Leste," 2016.

[12] H. Sapiri, N. Ahmad, N. Aziz, and F. Zainon, "Using Causal Loop Diagram in Understanding Financial Activities of Malaysia Pension Fund," Global Journal of Bussines and Social Science Review. ISSN 2289-8506, vol. 1 (2), no. January, pp. 359-364, 2015.

[13] J. Ryu, B. Contor, G. Johnson, R. Allen, and J. Tracy, "System Dynamics to Sustainable Water Resources Management in the Eastern Snake Plain Aquifer Under Water Supply Uncertainty," Journal of the American Water Resources Association (JAWRA), vol. JAWRA-11-0, pp. 12041220, 2012.

[14] S. Poespawardoyo, "Hidrogeological Map Of Indonesia, 1:250.000. Sheet No. X Kediri (Java)."

[15] J. L. Meyer et al., WHERE RIVERS ARE BORN: The Scientific Imperative for Defending Small Streams and Wetlands. American Rivers and Sierra Club, 2007.

[16] "Air Bersih: PDAM Malang Tawar Air Baku Sumberpitu Rp290/M3," 1st March 2013, 2013. [Online]. Available: http://www.airminum.or.id/airminum/air-bersih-pdam-malang-tawar-air- baku-sumberpitu-rp290m3. [Accessed: 13-Jul-2019].

[17] Z. Savasan, "Pollution, Water," in Encyclopedia of Big Data, no. January, 2017.

[18] M. R. Djuwansyah, "Environmental sustainability control by water resources carrying capacity concept: application significance in Indonesia Environmental sustainability control by water resources carrying capacity concept : application significance in Indonesia," Earth and Environmental Science, vol. 118, 2018. 
[19] D. Yohanes, "2 Sumber Air di Kabupaten Malang 'Dikuasai’ PDAM Kota Malang, Ini Komentar Dewan Artikel ini telah tayang di suryamalang.com dengan judul 2 Sumber Air di Kabupaten Malang 'Dikuasai' PDAM Kota Malang, Ini Komentar Dewan . . ., https://suryamalang.tribunnew," Surya Malang, 15 March 2017, 2017. [Online]. Available: https://suryamalang.tribunnews.com/2017/03/15/2sumber-air-di-kabupaten-malang-dikuasai-pdam-kota-malang-inikomentar-dewan. [Accessed: 13-Jul-2019].

[20] G. Qin, H. Li, X. Wang, and J. Ding, "Research on Water Resources Design Carrying Capacity,’Water MDPI, vol. 8, no. 157, 2016.

[21] Y. Qian, L. Tang, Q. Qiu, T. Xu, and J. Liao, “A Comparative Analysis on Assessment of Land Carrying Capacity with Ecological Footprint Analysis and Index System Method," PLOS One, pp.1-17, 2015.

[22] Yurike, Yonariza, R. Elhmirst, S. Karimi, and R. Febriamansyah, "Deforestation in Dharmasraya District, West Sumatra, Indonesia," Asian Journal of Scientific Research, vol. 11, no. 2, pp. 177-184, 2018.

[23] D. Ezzine-de-Blas, S. Wunder, M. Ruiz-Pérez, and R. del P. MorenoSanchez, "Global Patterns in the Implementation of Payments for Environmental Services," PLOS One, vol. 11(3): e01, 2016.

[24] C. Stevens, "Interpreting the Polluter Pays Principle in the Trade and Environment Context," Cornell Internationall Law Journal, vol. 27, no. 3, 1994.
[25] A. Zahar, "The Polluter-Pays Principle and its Implications for Environmental Governance in China," SSRN, vol. 20 May 201, pp. 1-22, 2017.

[26] H. Mahaseth, "Analysis of the Effectiveness of the Polluter Pays Principle in India," Social Science Research Network, vol. 10 March 2, pp. 1-8, 2019.

[27] M. Rondhi, P. A. Pratiwi, V. T. Handini, A. F. Sunartomo, and S. A. Budiman, "Agricultural Land Conversion, Land Economic Value, and Sustainable Agriculture: A Case Study in East Java, Indonesia," Land, 2018.

[28] H. Surtikanti, A. Syulasmi, and N. Ramdhani, "Traditional Knowledge of Local Wisdom of Ammatoa Kajang Tribe ( South Sulawesi ) about Environmental Conservation Traditional Knowledge of Local Wisdom of Ammatoa Kajang Tribe ( South Sulawesi ) about Environmental Conservation," in IOP Conf. Series: Journal of Physics: Conf. Series 895 (2017) 012122, 2017.

[29] Jundiani, "Local Wisdom in the Environmental Protection and Management," in IOP Conf. Series: Earth and Environmental Science 175 (2018) 012130 doi, 2018.

[30] M. G. Rindarjono, S. B. Ajar, and W. Purwanto, "Local Wisdom in Environmental Conservation," in IOP Conf. Series: Earth and Environmental Science 145 (2018) 012100, 2018. 